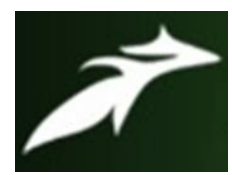

M.Sekhar et al, International Journal of Advances in Agricultural Science and Technology,

Vol.8 Issue.9, September-2021, pg. 163-174

ISSN: 2348-1358

Impact Factor: 6.057

NAAS Rating: 3.77

\title{
Millets as Nutre Cereals
}

\author{
M.Sekhar ${ }^{1}$; Abhishek Sagar ${ }^{2}$; Wasim Khan ${ }^{3}$; Jayant Patel ${ }^{4}$ \\ ${ }^{1}$ M.Sc.Agronomy, SHUATS \\ ${ }^{2 \& 3}$ Research Scholar, SHUATS \\ ${ }^{4}$ M.Sc. Horticulture, Rama University \\ Sekharm005@gmail.com
}

DOI: 10.47856/ijaast.2021.v08i9.018

\begin{abstract}
Among the growing population (136.64 crs as per2019) many people experience scarcity of food and all. In the 2020 Global Hunger Index, India ranks 94th out of the 107 countries with sufficient data to calculate $2020 \mathrm{GHI}$ scores. With a score of 27.2, India has a level of hunger that is serious (www.un.org/). The United Nations (UN) Food and Agriculture Organization (FAO) predicts that the on-going COVID-19 pandemic will increase this number as developing countries are double-hit by disease and hunger (www.fao.org/2019-ncov/q-and-a/) Disruptions in global supply chains, economic consequences (i.e., loss of jobs and incomes), the ban on the export of agricultural commodities, and price increases are the major reasons for this crisis. Although much attention is being given to the development of vaccines, therapeutic molecules, and preventive measures to combat COVID-19, the invisible threat to the lives and livelihoods of marginal populations through hunger and malnutrition remains largely unaddressed. The focus of the 2019 Global hunger index on 'The Challenge of Hunger and Climate Change' underlines the impacts of changing climates on agriculture that include crop failures owing to problems such as seasonal fluctuations, increased insect and pest attacks, and broad-spectrum infection by potential pathogens (www.globalhungerindex.org/).Supplying food grains is an immediate measure to aid the affected population, whereas devising long-term plans to prevent such challenges is the need of the hour. That said, the possibility of a second and third wave of COVID-19 in the near future should not be ignored. In such a case, the UN World Food Programme predicts (UN-WFP; https://insight.wfp.org/) that death due to lack of food would outnumber deaths caused by disease infection. The importance of crop diversity and of mainstreaming underutilized crops that could serve as functional foods has been pointed out before; however, identifying the best candidates of underutilized crops and deploying crop improvement strategies to release better varieties is still in a nascent stage. Mayes et al. Other plant species, including tubers, legumes, and leafy vegetables, also fall within the criteria of underutilized species; however, emphasis is given to small millets because they are capable of reducing the overdependence on major cereals. Three major cereals, namely rice, wheat, and maize, cater for up to $60 \%$ of the global food requirements, and this is one of the plausible causes of food and nutritional inadequacies in the hunger hotspots where these crops are largely imported for consumption. Millets, although cultivated marginally in those regions, have the potential to address these inadequacies if their area of cultivation is increased and crop improvement strategies are devised and deployed.
\end{abstract}

Keywords: Millets, Underutilized crop, Nutri cereal, God owns crop, wonder grain 


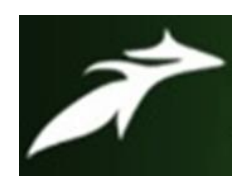

M.Sekhar et al, International Journal of Advances in Agricultural Science and Technology, Vol.8 Issue.9, September-2021, pg. 163-174

ISSN: 2348-1358

Impact Factor: 6.057

NAAS Rating: 3.77

\section{INTRODUCTION}

Millets, believes as God's Own Crops, are truly wonder grains. They can grow on the most marginalized soils - without irrigation, and with very little or sometimes no external inputs. They are veritable storehouses of health and nutrition. Besides, millets are also the pivot around which a vibrant agro biodiversity survives, wherever it is allowed to survive .But unfortunately over the decades, the state policies have progressively eroded both the millets as well as all the brilliant farming systems they have represented. Consequently, hundreds of thousands of hectares dedicated to growing millets have degenerated into cultivable fallows, and their size currently stands at a massive 30 million hectares. The millet acreage over the last couple of decades has shrunk from 18 million hectares to 9 million hectares, thus depriving the poor of their nutritional food, livelihood, security and control over their farming.

\section{Small Millets Offer a Sustainable Alternative to Major Staple Crops}

'Small millets' is a generic term that denotes the coarse cereals. It includes finger millet (Eleusine coracana), foxtail millet (Setaria italica), proso millet (Panicum miliaceum), barnyard millet (Echinochloa crus-galli), kodo millet (Paspalum scrobiculatum), little millet (Panicum sumatrense), teff (Eragrostis tef), fonio (Digitaria exilis), Job's tears (Coix lacryma-jobi), guinea millet (Brachiaria deflexa), and browntop millet (Urochloa ramosa) [트므 (Figure 1 ).

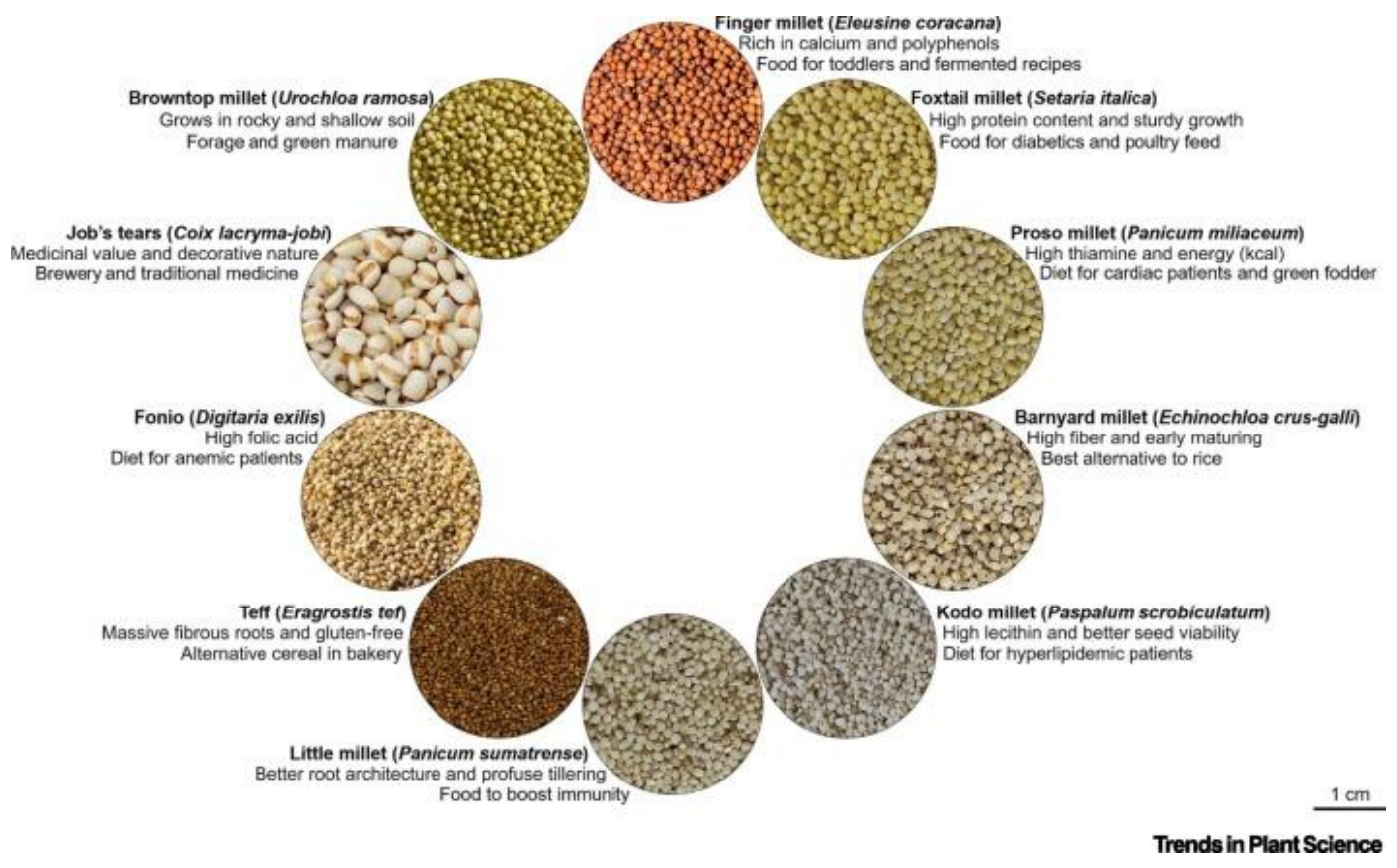




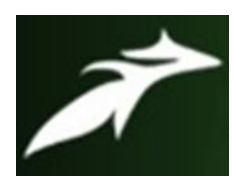

M.Sekhar et al, International Journal of Advances in Agricultural Science and Technology,

Vol.8 Issue.9, September-2021, pg. 163-174

ISSN: 2348-1358

Impact Factor: 6.057

NAAS Rating: 3.77

In terms of agro ecological traits, millets have better water-use and nitrogen-use efficiencies that enable them to withstand water-limiting conditions $\left[{ }^{10}\right]$. For example, foxtail millet requires $\sim 250 \mathrm{~g}$ of water to produce $1 \mathrm{~g}$ of dry biomass, whereas wheat and maize require $\sim 450$ and $500 \mathrm{~g}$, respectively $\left[{ }^{[11}\right]$. Similarly, a study in finger millet reported a requirement of nitrogen fertilizer as low as $20-60 \mathrm{~kg} / \mathrm{ha}$ for better productivity $\left[{ }^{12}\right]$. Small millets are also rich in micro- and macro-nutrients, total protein, fiber, and resistant starch. For instance, finger millet is rich in calcium $(\sim 364 \mathrm{mg}$ per $100 \mathrm{~g})$ and potassium $(\sim 320 \mathrm{mg}$ per $100 \mathrm{~g})$, and little millet and barnyard millet have high iron contents $(\sim 10-18 \mathrm{mg}$ per $100 \mathrm{~g})$. The total protein is high in foxtail millet and barnyard millet $(>10 \%)$, and crude fiber is rich in barnyard millet, little millet, foxtail millet, and fonio $(\sim 7-14 \%)\left[\frac{13}{3}\right.$. Further, the majority of small millets are gluten-free, and therefore facilitate the preparation of low glycemic index products $[\underline{14,15}]$.

Fig: Millets an approach for sustainable agriculture and healthy world

\begin{tabular}{|c|c|c|c|}
\hline \multicolumn{4}{|c|}{ Millets: an approach for sustainable agriculture and healthy world } \\
\hline$\downarrow$ & $\sqrt{ }$ & $\downarrow$ & $\sqrt{ }$ \\
\hline $\begin{array}{l}\text { Food Secuity } \\
\text { - Sustainable food } \\
\text { source for combating } \\
\text { hunger in changing } \\
\text { world climate } \\
\text { - Resistant to climatic } \\
\text { stress, pests and } \\
\text { diseases }\end{array}$ & $\begin{array}{l}\text { Nutritional Secuity } \\
\text { - Rich in } \\
\text { micronutrients like } \\
\text { calcium, iron, zinc, } \\
\text { iodine etc. } \\
\text { - Rich in bioactive } \\
\text { compounds } \\
\text { Better amino acid } \\
\text { profile }\end{array}$ & $\begin{array}{l}\text { Safety from diseases } \\
\text { - Gluten free: a } \\
\text { substitute for wheat } \\
\text { in celiac diseases } \\
\text { - Low GI: a good food } \\
\text { for diabetic persons } \\
\text { - Can help to combat } \\
\text { cardiovascular } \\
\text { diseases, anaemia, } \\
\text { calcium deficiency } \\
\text { etc. }\end{array}$ & $\begin{array}{l}\text { Economic secuity } \\
\text { - Climate resilient crop } \\
\text { - Sustainable income } \\
\text { source for farmers } \\
\text { - Low investment } \\
\text { needed for production } \\
\text { - Value addition can } \\
\text { lead to economic } \\
\text { gains }\end{array}$ \\
\hline
\end{tabular}

\section{Recent Progress in Millet Research}

Genetic and genomic resources are imperative for crop improvement, where genetic resources serve as the primary input for breeding and research, and genomic resources facilitate the efficient characterization of genetic resources and their utilization in crop improvement. In terms of genetic resources, 164447 cultivated and wild germplasms of small millets are conserved in genebanks worldwide (www.fao.org/). However, the majority of the germplasms belong to finger millet, foxtail millet, and proso millet, whereas the representation of other small millets is minimal. Several germplasms were lost in the process of shifting to cash crops, and an intensive drive will be necessary to conserve the remaining material before this is permanently lost. In terms of genomic resources, whole-genome sequencing (WGS) of foxtail millet, green foxtail, finger millet, barnyard millet, and teff [ㄷ.6, 27., 28., 29., 30.] was performed to identify the novel genes, alleles, and quantitative trait loci 


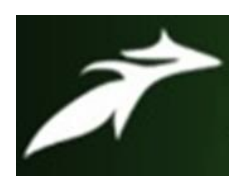

M.Sekhar et al, International Journal of Advances in Agricultural Science and Technology,

Vol.8 Issue.9, September-2021, pg. 163-174

ISSN: 2348-1358

Impact Factor: 6.057

NAAS Rating: 3.77

underlying yield-determining, agronomic, and climate-resilience traits (reviewed in $\left[{ }^{33}\right]$ ). The WGS data are available in databases including Phytozome (https://phytozome.jgi.doe.gov/), Gramene (www.gramene.org/), and EnsemblPlants (https://plants.ensembl.org/). This has facilitated the development of large-scale, genome-wide molecular markers $\left[{ }^{34}\right]$, the construction of high-density maps $[\underline{35}, \underline{36}, \underline{37}]$, and the identification of genomic regions governing key traits for use in breeding programs [ $[\underline{38}, \underline{39 .}, \underline{40 .}, \underline{41}, \underline{42}$.$] .$

Given the availability of these resources, small millet breeding programs presently focus on resolving production constraints. Lodging and seed-shattering are major problems in millet cultivation $\left[\frac{43}{}\right]$, and in kodo millet, mutation-breeding has shown promising results to develop improved non-lodging varieties $\left[{ }^{44}\right]$. In addition, there are specific genetic traits of interest that have received less research attention. Notably, genetic determinants of grain micronutrient content were studied to a limited extent in small millets. In foxtail millet, Jaiswal et al. $\left[{ }^{40}\right]$ identified 74 marker-trait associations for 10 micronutrient traits through GWAS. Recently, Puranik et al. $\left[^{[\underline{42}]}\right.$ performed GWAS in finger millet to identify 418 SNPs linked to micronutrient content. These studies should be extended to enable genomicsassisted breeding for the development of improved varieties with high micronutrient content. Resistant starch content is another important trait specific to millet grain that awaits scientific intervention to unravel its genetics and genomics $[\underline{45}]$. Other prospective areas of research in millets as compared to major cereals include $\mathrm{C}_{4}$ photosynthetic traits $\left[{ }^{46,47}\right]$ and tolerance to multiple environmental stresses $[\underline{48, \underline{49}}]$, the development and characterization of male sterility systems $\left[\frac{33,50}{}\right]$, enhancing the shelf-life (rancidity issues) [ $[\underline{51}]$, reducing grain antinutrients including phytates, phenols, tannins, and enzyme inhibitors [ㄴ.5‥53. $]$, and addressing the issues of lodging and seed-shattering $[\underline{43}, \underline{55}]$. A recent study also reported an increased incidence of insect pests, wherein up to 150 different species were found to attack millets at different growth and developmental stages [ $\left.{ }^{31}\right]$. Identifying resistant germplasms and investigating them using omic tools will facilitate the development of elite lines with enhanced resistance to insect pests. Many research programs are going national and internationally to enchase quality and resist of millets.

Table 2: Millets germplasm at ICRISAT gene bank

\begin{tabular}{|l|l|l|l|}
\hline Crop & Active collection & Base collection & Source countries \\
\hline Pearl millet & 21594 & 17670 & 50 \\
\hline Finger millet & 5945 & 4620 & 24 \\
\hline Foxtail millet & 1535 & 1034 & 26 \\
\hline Proso millet & 842 & 576 & 30 \\
\hline Little millet & 466 & 384 & 5 \\
\hline Kodo millet & 658 & 630 & 2 \\
\hline Barnyard millet & 743 & 487 & 9 \\
\hline
\end{tabular}

Source: International Crops Research Institute for Semi-Arid Tropics [ICRISAT], Hyderabad 


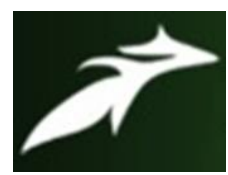

M.Sekhar et al, International Journal of Advances in Agricultural Science and Technology,

Vol.8 Issue.9, September-2021, pg. 163-174

ISSN: 2348-1358

Impact Factor: 6.057

NAAS Rating: 3.77

Health Benefits of Millets:

Millets are anti-acidic, gluten free detoxify body, Niacin (vitamin B3) in millet can help lower cholesterol, they Prevents breast cancer and helps to prevent type 2 diabetes (Kam J et.al.). They are effective in reducing blood pressure which helps to protect against heart diseases .They also aids in treating respiratory conditions such as asthma .Helps to optimize kidney, liver and immune system health ,Reduces risk of gastrointestinal conditions like gastric ulcers or colon cancer. Reduces risk of gastrointestinal conditions like gastric ulcers or colon cancer Eliminates problems like constipation, excess gas, bloating and cramping. Millet acts as a prebiotic feeding microflora in your inner ecosystem

Table: Nutritional Benefits of Millets (for 100g of each millet)

\begin{tabular}{|l|l|l|l|l|l|}
\hline & Protein(g) & Fiber(g) & Mineral(g) & Iron(mg) & Calcium(mg) \\
\hline Sorghum & 10 & 4 & 1.6 & 2.6 & 54 \\
\hline Pearl millet & 10.6 & 1.3 & 2.3 & 16.9 & 38 \\
\hline Finger millet & 7.3 & 3.6 & 2.7 & 3.9 & 344 \\
\hline Foxtail millet & 12.3 & 8 & 3.3 & 2.8 & 31 \\
\hline Proso millet & 12.5 & 2.2 & 1.9 & 0.8 & 14 \\
\hline Kodo millet & 8.3 & 9 & 2.6 & 0.5 & 27 \\
\hline Little millet & 7.7 & 7.6 & 1.5 & 9.3 & 17 \\
\hline Barnyard millet & 11.2 & 10.1 & 4.4 & 15.2 & 11 \\
\hline Teff & 13 & 8 & 0.85 & 7.6 & 180 \\
\hline Fonio & 11 & 11.3 & 5.31 & 84.8 & 18 \\
\hline $\begin{array}{l}\text { Brown } \\
\text { millet }\end{array}$ & 11.5 & 12.5 & 4.2 & 0.65 & \\
\hline
\end{tabular}




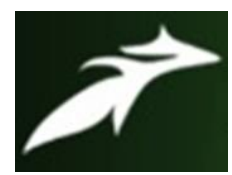

M.Sekhar et al, International Journal of Advances in Agricultural Science and Technology, Vol.8 Issue.9, September-2021, pg. 163-174

ISSN: 2348-1358

Impact Factor: 6.057

NAAS Rating: 3.77

Top 10 Millet Producing States in India [States with Highest Millet Production]

1. Rajasthan:

Agriculture sector has played a major role in encouraging farmers on millet production. Thus, Rajasthan is on the top in the list with total produce of 3750.00 tonnes and a share of $41.03 \%$.

2. Uttar Pradesh:

UP grabbed the the second position in bajra (millet) production. As per the records of 2018, the total produce was recorded to be $\mathbf{1 8 0 0 . 0 0}$ tonnes and a share of $\mathbf{1 9 . 6 9 \%}$. The state has a major share in the total millet production of India

\section{Gujarat:}

Gujarat's total millet production counts to $\mathbf{9 2 0 . 0 0}$ tonnes. To be precise, it means the share is $10.07 \%$ to India. We just began to share about the top states in India based on millet production.

\section{Madhya Pradesh:}

The total collection of millets by MP as of 2018 records was $\mathbf{7 6 0 . 0 0}$ tonnesand thus, the state's share to India is $8.32 \%$. Continue to read as there is a lot to share about the other states in relation to millets.

\section{Haryana:}

Haryana enjoys being on the fifth position in millet cultivation and the state is trying hard to go up the level in its total millets produce in coming years. As of 2018, the production went up to $\mathbf{7 5 0 . 0 0}$ tonnes and the share has been $7.88 \%$.

\section{Maharashtra:}

The state enjoys sixth position amongst the top states in India based on millet production. The share has been 610.00 tonnes with a share of $6.67 \%$.

\section{Karnataka:}

Karnataka's total millet production has been 290.00 tonnes with a share of 3.17 to the country. The state plays a major role in the other crops' production too.

\section{Tamil Nadu:}

The Government of Tamil Nadu has also taken all the necessary steps to promote millets production in its state. Together, Karnataka, Odisha, and Tamil Nadu have announced an INR 100 crore mission on millets production. Read more to know more about the remaining states amongst $\mathbf{1 0}$ largest millet producing states of India.

\section{Odhisa:}

Tribal people of Odisha are majorly involved in the production of millets. As per the record of 2018, about $\mathbf{2 4 , 4 9 9}$ farmers have registered for the production of millets and ragi.

\section{Kerala:}

Kerala also knows the importance of millet production in India. Pearl millets also known as Bajra are highly rich source of energy, promotes good health, and prevents weight gain. 


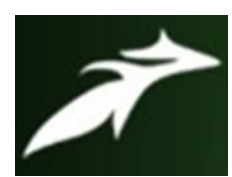

M.Sekhar et al, International Journal of Advances in Agricultural Science and Technology, Vol.8 Issue.9, September-2021, pg. 163-174

ISSN: 2348-1358

Impact Factor: 6.057

NAAS Rating: 3.77

There are several other states that are known for paying attention in millet production. If there are any queries or comments you would like to share related to the article, kindly drop your comments. Also, let us know how you found the article on $\mathbf{1 0}$ Largest millet producing states of India.

Source: https://theindianblog.in/top-10-states-india/top-10-millet-producing-states-in-india/

Advantages of Millets:

Millets grow on the poorest of soils:

Most millets can be grown on low fertility soils. Some in acidic soils, some on saline soils. Millets such as Pearl millet can also be grown on sandy soils, as is done in Rajasthan. In fact, finger millet grows well in saline soils. Barnyard millet too thrives in problem soils, where other crops like rice, struggle to grow in such soils. Many of them are also grown to reclaim soils. Poor farmers especially in dry land India are owners of very poor lands. Much of the cultivable fallows and low fertility farms have been handed to them through the process of land reforms.

Millets do not demand synthetic fertilisers:

Millets do not demand chemical fertilizers. In fact, under dry land conditions, millets grow better in the absence of chemical fertilizers. Therefore, most millet farmers grow them using farmyard manure under purely eco-friendly conditions. In recent years farmers have also started using bio fertilisers such as vermicomposting produced in their backyard and growth promoters such as panchagavya, amrit pani etc. These practices make millet production not only eco-friendly but stays under the control of farmers.

Millets are pest free crops:

Growing traditional local landraces and under ecological conditions, most millets such as foxtail are totally pest free and hence do not need any pesticides. Even in storage conditions, most millets such as foxtail not only not need any fumigants, but act as anti pest agents to store delicate pulses such as green gram.

Millets are not just crops but a cropping system:

Most millets grown under traditional practices are a Farming System and not just a crop. Most millet fields are inherently bio diverse. This is the tradition of millet farming in the country. Six to twenty crops are planted on the same space at the same time

Millets produce multiple security:

While single crops such as rice and wheat can succeed in producing food security for India millets produce multiple securities. They include securities of food, nutrition, fodder, fibre, health, livelihood and ecology. 


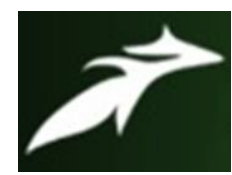

M.Sekhar et al, International Journal of Advances in Agricultural Science and Technology, Vol.8 Issue.9, September-2021, pg. 163-174

ISSN: 2348-1358

Impact Factor: 6.057

NAAS Rating: 3.77

Millets are climate change compliant crops:

Due to all the qualities mentioned above, Millets remain our agricultural answer to the climate crisis that the world is facing. Climate Change is expected to confront us with three challenges. Increase in temperature up to 2-5 degree Celsius Increasing water stress Severe malnutrition Since they are already capable of growing under drought conditions, they can withstand higher heat regimes.

Millets grow under non-irrigated conditions in such low rainfall regimes as between $200 \mathrm{mmand} 500 \mathrm{~mm}$. Thus, they can also face the water stress and grow. Each of the millets is a storehouse of dozens of nutrients in large quantities. They include major and micro nutrients needed by the human body. Hence they can help people withstand malnutrition.

\section{Recognising and retrieving millets Policy matters}

1. Millets are water saving, drought tolerant crops. Therefore they must be viewed as climate change compliant crops. This quality makes them India's food and farming future. This is the perspective from which the millet cultivation and its promotion must be regarded. Every millet farmer of India must be given a climate change bonus, biodiversity bonus, water conservation bonus.

2. The urgent and immediate need is to put millets into the Public Distribution System. Different parts of India grow diverse kinds of millets. Rajasthan is home to Pearl Millet (Bajra). Deccan plateau (Marathwada in Maharashtra, Telangana in Andhra Pradesh and North Karnataka in Karnataka) is well known for sorghum. Southern Andhra Pradesh, Tamil Nadu, Orissa and Southern Karnataka are the home of Finger millet. Uttarakhand and otherhill and tribal areas cultivate a range of small millets such as Foxtail, Proso, Kodo and Barnyard. The Indian PDS system will be enriched with the high nutritive quality of these millets if they are included in it.

3. A nutritive analysis of millets vis a vis the major grains such as rice and wheat prove that nutrient to nutrient, millets score highly over the other grains. Compared to rice, they have 30 to $300 \%$ more nutritional elements such as Calcium, Minerals, Iron, Fibre, Beta Carotine and many other micronutrients. Therefore the inclusion of millets in PDS will make PDS a food and nutritional security programme.

4. The pro millet PDS paradigm must depend on a completely decentralized approach based on the principle of local production, local storage and local distribution. This must be supported by the government, both in procurement and in storage. This will resolve the question of availability and keeping quality.

5. Government must urgently provide space for millet based foods in the ICDS, schoolmeals and welfare hostel programmes. This will overcome the problem of malnutrition of young children a problem where India fares worse than the sub Saharan region, the poorestin the world.

6. All these actions, together will open up new markets for millet farmers and revitalize them.

7. There are a number of institutional mechanisms that needs to be created, nurtured and developed. Millets need a number of enabling conditions. The principal among these is to increase livestock which are local breeds and 


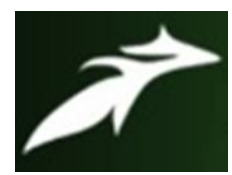

M.Sekhar et al, International Journal of Advances in Agricultural Science and Technology, Vol.8 Issue.9, September-2021, pg. 163-174

ISSN: 2348-1358

Impact Factor: 6.057

NAAS Rating: $\mathbf{3 . 7 7}$

adapted to local ecosystems. This will create a symbiotic relationship between farming and pastoralism, such as increased organic manure, fodder availability, milk production and increased incomes for farmers.

8. Urgent attention must be given to the productivity enhancement of the rainfed lands where millets are grown. This could be achieved through special watersheds on millet dovetailing government's employment programmes such as NREGA to support milletcultivation from sowing to harvesting

9. Millet farms are intrinsically bio diverse. Therefore farming system development should become the aim and not single crop development. The monitoring, evaluation and research on millet cultivation must be tailored to this special quality of millet farming system. Policy makers must take note of the fact that millets make way for a dynamic diversity on farmers fields.

10. Millets can be cultivated without using groundwater or surface irrigation. Their energy requirement from sources such as chemical fertilizers, pesticides, water and power can be near zero. This amazing capacity of this production system must be honoured through offering socio-ecological bonusto millet growing farmers. Appropriate institutional mechanisms must be developed to assess this.

11. Institutional finance and insurance which is offered generously to farmers who cultivate preferred grains such as rice and wheat and non food crops must be extended to millet farmersalso.

Research institutions must give a new thrust on millet areas and issues. But such research initiatives must be led by farmers since they offer exciting perspectives for the research which has to be people-centered and people directed

\section{CONCLUSION:}

\section{Only millets have the capacity to meet this challenge:}

Since they are already capable of growing under drought conditions, they can withstand higher heat regimes, Millets grow under non-irrigated conditions in such low rainfall regimes as between $200 \mathrm{~mm}$ and 500 $\mathrm{mm}$. Thus, they can also facethe water stress and grow, Each of the millets is a storehouse of dozens of nutrients in largequantities. They include major and micro nutrients needed by thehuman body. Hence they can help people withstand malnutrition

In view of all these features that they so amazingly combine, millets can only be called as Miracle Grain 


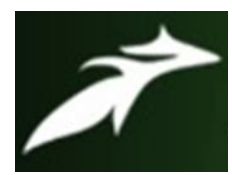

M.Sekhar et al, International Journal of Advances in Agricultural Science and Technology, Vol.8 Issue.9, September-2021, pg. 163-174

ISSN: 2348-1358

Impact Factor: 6.057

NAAS Rating: 3.77

\section{References}

- CSE (2007), "Rainfed Areas of India-Center for Science and environment", downloaded on 29th July 2009 from http://www.cseindia.org/programme/nrml/rainfed_specials.htm

- DoMD, "Area and Production analysis of millets in India", Directorate of Millets Development (DoMD), Ministry of

- Agriculture and Cooperation, Government of India, downloaded on 25th July 2009 from http://dacnet.nic.in/millets/all_india_apy_trend.htm

- Sharma.J (2007), "National Conference on Argiculture for Rabi Campaign 2007” Presentation by Dr, J.S. Sharma, CEO,

- National Rainfed Agriculture Authority", downloaded on 29th July 2009 from http://agricoop.nic.in/Rabi\%20Conferenc

- $\quad$ https://theindianblog.in/top-10-states-india/top-10-millet-producing-states-in-india/

- International Crops Research Institute for Semi-Arid Tropics [ICRISAT], Hyderabad

[1]. Xu S., Li Y. Beware of the second wave of COVID-19. Lancet. 2020;395:1321-1322. [PMC free article] [PubMed] [Google Scholar]

[2]. Padulosi S. Underutilised crops: trends, challenges and opportunities in the 21st century. In: Engels J.M.M., editor. Managing Plant Genetic Diversity. Vol. 30. IPGRI; 2002. pp. 323-338. [Google Scholar]

[3]. Dawson I.K. The role of genetics in mainstreaming the production of new and orphan crops to diversify food systems and support human nutrition. New Phytol. 2019;224:37-54. [PubMed] [Google Scholar]

[4]. Mayes S. The potential for underutilized crops to improve security of food production. J. Exp. Bot. 2012;63:1075-1079. [PubMed] [Google Scholar]

[5]. Muthamilarasan M. Multi-omics approaches for strategic improvement of stress tolerance in underutilized crop species: a climate change perspective. Adv. Genet. 2019;103:138. [PubMed] [Google Scholar]

[6]. Goron T.L., Raizada M.N. Genetic diversity and genomic resources available for the small millet crops to accelerate a new green revolution. Front. Plant Sci. 2015;6:157. [PMC free article] [PubMed] [Google Scholar]

[7]. Bandyopadhyay T. Millets for next generation climate-smart agriculture. Front. Plant Sci. 2017;8:1266. [PMC free article] [PubMed] [Google Scholar]

[8]. Arora R.K. Job's-tears (Coix lacryma-jobi) - a minor food and fodder crop of Northeastern India. Econ. Bot. 1977;31:358-366. [Google Scholar]

[9]. Weber S. Out of Africa: the initial impact of millets in South Asia. Curr. Anthropol. 1998;39:267274. [Google Scholar]

[10].Fuller D.Q. Early plant domestications in Southern India: some preliminary archaeobotanical results. Veg. Hist. Archaeobot. 2004;13:115-129. [Google Scholar]

[11].Feldman M.J. Components of water use efficiency have unique genetic signatures in the model C4 grass Setaria. Plant Physiol. 2018;178:699-715. [PMC free article] [PubMed] [Google Scholar] 


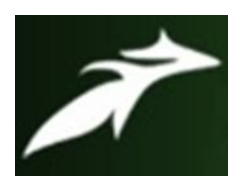

M.Sekhar et al, International Journal of Advances in Agricultural Science and Technology, Vol.8 Issue.9, September-2021, pg. 163-174

ISSN: 2348-1358

Impact Factor: 6.057

NAAS Rating: 3.77

[12].Li P., Brutnell T.P. Setaria viridis and Setaria italica, model genetic systems for the panicoid grasses. J. Exp. Bot. 2011;62:3031-3037. [PubMed] [Google Scholar]

[13].Pradhan A. Effect of different nitrogen levels on kodo and finger millet under rainfed conditions. Res. J. Agri. Sci. 2011;2:136-138. [Google Scholar]

[14].Muthamilarasan M. Exploration of millet models for developing nutrient rich graminaceous crops. Plant Sci. 2016;542:89-97. [PubMed] [Google Scholar]

[15].Taylor J.R.N., Emmambux M.N. Gluten-free foods and beverages from millets. In: Gallagher E., editor. Gluten-Free Cereal Products and Beverages. Elsevier; 2008. pp. 1-27. [Google Scholar]

[16].Naser H.M.N. Carbon sequestration and contribution of $\mathrm{CO}_{2}, \mathrm{CH}_{4}$ and $\mathrm{N}_{2} \mathrm{O}$ fluxes to global warming potential from paddy-fallow fields on mineral soil beneath peat in Central Hokkaido, Japan. Agriculture. 2019;10:6. [Google Scholar]

[17].Saleh A.S.M. Millet grains: nutritional quality, processing, and potential health benefits. Compr. Rev. Food Sci. Food Saf. 2013;12:281-295. [Google Scholar]

[18].Garn S.M., Leonard W.R. What did your ancestors eat? Nutr. Rev. 1989;47:337345. [PubMed] [Google Scholar]

[19].Collins W.W., Hawtin G.C., editors. Biodiversity in Agroecosystems. CRC Press; 1999. [Google Scholar]

[20]. Chivenge P. The potential role of neglected and underutilised crop species as future crops under water scarce conditions in Sub-Saharan Africa. Int. J. Environ. Res. Public Health. 2015;12:56855711. [PMC free article] [PubMed] [Google Scholar]

[21].Rodríguez J.P. Healthy and resilient cereals and pseudo-cereals for marginal agriculture: molecular advances for improving nutrient bioavailability. Front. Genet. 2020;11:49. [PMC free article] [PubMed] [Google Scholar]

[22].Lebot V. CABI; 2009. Tropical Root and Tuber Crops: Cassava, Sweet Potato, Yams and Aroids. [Google Scholar]

[23].Gulzar M., Minnaar A. Underutilized protein resources from african legumes. In: Wanasundara J.P.D., Scanlin L., editors. Sustainable Protein Sources. Academic Press; 2019. pp. 197-208. [Google Scholar]

[24].Cummings J.H., Englyst H.N. Gastrointestinal effects of food carbohydrate. Am. J. Clin. Nutr. 1995;61:938S-945S. [PubMed] [Google Scholar]

[25].Annor G.A. Why do millets have slower starch and protein digestibility than other cereals? Trends Food Sci. Technol. 2017;66:73-83. [Google Scholar]

[26].Bennetzen J.L. Reference genome sequence of the model plant Setaria. Nat. Biotechnol. 2012;30:555561. [PubMed] [Google Scholar]

[27].Zhang G. Genome sequence of foxtail millet (Setaria italica) provides insights into grass evolution and biofuel potential. Nat. Biotechnol. 2012;30:549-554. [PubMed] [Google Scholar]

[28].Hittalmani S. Genome and transcriptome sequence of finger millet (Eleusine coracana (L.) Gaertn.) provides insights into drought tolerance and nutraceutical properties. BMC Genomics. 2017;18 [PMC free article] [PubMed] [Google Scholar]

[29].Guo L. Echinochloa crus-galli genome analysis provides insight into its adaptation and invasiveness as a weed. Nat. Commun. 2017;8:1031. [PMC free article] [PubMed] [Google Scholar]

[30].Van Buren R. Exceptional subgenome stability and functional divergence in the allotetraploid Ethiopian cereal teff. Nat. Commun. 2020;11 [PMC free article] [PubMed] [Google Scholar]

[31].Gahukar R.T., Reddy G.V.P. Management of economically important insect pests of millet. J. Integr. Pest. Manag. 2019;28:1-10. [Google Scholar]

[32].Nicoletti M. Nutraceuticals and botanicals: overview and perspectives. Int. J. Food Sci. Nutr. 2012;63:2-6. [PubMed] [Google Scholar]

[33]. Vetriventhan M. Genetic and genomic resources, and breeding for accelerating improvement of small millets: current status and future interventions. Nucleus. 2020 doi: 10.1007/s13237-020-003223. Published online July 4, 2020. [CrossRef] [Google Scholar]

[34].Rajendrakumar P. Molecular markers for the genetic improvement of millets. In: Patil J.V., editor. Millets and Sorghum: Biology and Genetic Improvement. John Wiley \& Sons; 2017. pp. 341394. [Google Scholar] 


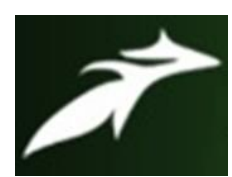

M.Sekhar et al, International Journal of Advances in Agricultural Science and Technology, Vol.8 Issue.9, September-2021, pg. 163-174

ISSN: 2348-1358

Impact Factor: 6.057

NAAS Rating: 3.77

[35].Fang X. A high density genetic map and QTL for agronomic and yield traits in foxtail millet [Setaria italica (L.) P. Beauv.] BMC Genomics. 2016;17 [PMC free article] [PubMed] [Google Scholar]

[36]. Wang J. A high-density genetic map and QTL analysis of agronomic traits in foxtail millet [Setaria italica (L.) P. Beauv.] using RAD-seq. PLoS One. 2017;12 [MC free article] [PubMed] [Google $\underline{\text { Scholar] }}$

[37].Ni Q.X. Updated foxtail millet genome assembly and gene mapping of nine key agronomic traits by resequencing a RIL population. GigaScience. 2017;6 [PMC free article] [PubMed] [Google Scholar]

[38]. Sharma D. Genome wide association mapping of agro-morphological traits among a diverse collection of finger millet (Eleusine coracana L.) genotypes using SNP markers. PLoS One. 2018;13 [PMC free article] [PubMed] [Google Scholar]

[39].Jaiswal V. Genome-wide association study of major agronomic traits in foxtail millet (Setaria italica L.) using ddRAD sequencing. Sci. Rep. 2019;9 [PMC free article] [PubMed] [Google Scholar]

[40].Jaiswal V. Genome-wide association study (GWAS) delineates genomic loci for ten nutritional elements in foxtail millet (Setaria italica L.) J. Cereal Sci. 2019;85:48-55. [Google Scholar]

[41].Liu T. QTL mapping of yield component traits on bin map generated from resequencing a RIL population of foxtail millet (Setaria italica)BMC Genomics. 2020;21:141. [PMC free article] [PubMed] [Google Scholar]

[42].Puranik S. Genome-wide association mapping and comparative genomics identifies genomic regions governing grain nutritional traits in finger millet (Eleusine coracana L. Gaertn.) Plants People Planet. 2020 doi: 10.1002/ppp3.10120. Published online July 5, 2020. [CrossRef] [Google Scholar]

[43].Tian B. Penalties in yield and yield associated traits caused by stem lodging at different developmental stages in summer and spring foxtail millet cultivars. Field Crops Res. 2018;217:104-112. [Google Scholar]

[44].Jency J.P. Induced mutagenesis enhances lodging resistance and photosynthetic efficiency of kodomillet (Paspalum scrobiculatum) Agronomy. 2020;20:227. [Google Scholar]

[45].Kam J. Dietary interventions for type 2 diabetes: how millet comes to help. Front. Plant Sci. 2016;7:1454. [PMC free article] [PubMed] [Google Scholar]

[46].Huang P., Brutnell T.P. A synthesis of transcriptomic surveys to dissect the genetic basis of C4 photosynthesis. Curr. Opin. Plant Biol. 2016;31:91-99. [PubMed] [Google Scholar]

[47].Luo M. Screening of mutants related to the $\mathrm{C} 4$ photosynthetic Kranz structure in foxtail millet. Front. Plant Sci. 2018;9:1650. [PMC free article] [PubMed] [Google Scholar]

[48].Satyavathi C.T. In: Genomics assisted breeding for abiotic stress tolerance in millets. In Genomics Assisted Breeding of Crops for Abiotic Stress Tolerance (Vol. II), Sustainable Development and Biodiversity. Rajpal V., editor. Vol. 21. Springer; 2019. pp. 241-255. [Google Scholar]

[49].Nadeem F. Adaptation of foxtail millet (Setaria italica L.) to abiotic stresses: a special perspective of responses to nitrogen and phosphate limitations. Front. Plant Sci. 2020;11:187. [PMC free article] [PubMed] [Google Scholar]

[50]. Wang J. Genetic analysis and preliminary mapping of a highly male-sterile gene in foxtail millet (Setaria italica L. Beauv.) using SSR markers. J. Integr. Agric. 2013;12:2143-2148. [Google Scholar]

[51].Čepková P.H. Rancidity development in millet species stored in different storage conditions and evaluation of free fatty acids content in tested samples. J. Food Agric. Environ. 2014;12:101106. [Google Scholar]

[52].Mbithi-Mwikya S. Nutrient and antinutrient changes in finger millet (Eleusine coracan) during sprouting. LWT-Food Sci. Technol. 2000;33:9-14. [Google Scholar]

[53]. Devisetti R. Nutrients and antinutrients in foxtail and proso millet milled fractions: evaluation of their flour functionality. LWT-Food Sci. Technol. 2014;59:889-895. [Google Scholar]

[54]. Satheesh N., Fanta S.W. Review on structural, nutritional and anti-nutritional composition of Teff (Eragrostis tef) in comparison with quinoa (Chenopodium quinoa Willd.) Cogent Food Agric. 2018;4 [Google Scholar]

[55].Tian B. Assessment of resistance to lodging of landrace and improved cultivars in foxtail millet. Euphytica. 2010;172:295-302. [Google Scholar] 